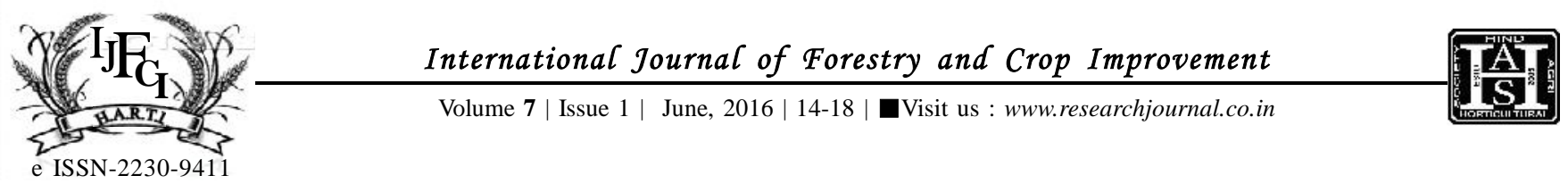

\title{
Strategies for weed management in drum seeded rice under puddled condition (Oryza sativa L.)
}

\author{
T. PARTHIPAN
}

\begin{abstract}
Wet seeding holds special significance in the present day production systems by saving time, labour and energy. Drum seeded rice in puddled land becoming popular as lowland rice establishment method. Yield losses caused by weeds will become greater in direct seeding because of simultaneous growth of both rice and weed seedlings from the beginning. Weeds pose serious threat to sustainability and viability of direct seeded rice system. In this context, field experiments were conducted at Tamil Nadu Rice Research Institute, Aduthurai during wet seasons of 2011-12 and 2012-13 to evaluate the integrated weed management practices for lowland drum seeded rice in Cauvery Delta Zone. A total of 12 treatments were evaluated in a Randomized Block Design with three replications. The treatments consisted of post emergence application of metamifop $(75,100,125 \mathrm{~g}$ ai $\mathrm{ha}^{-1}$ ), pre-emergence application of pretilachlor plus safener @ $0.45 \mathrm{~kg} \mathrm{ai} \mathrm{ha}^{-1}$ alone and in combination with one hand weeding on 45 DAS; Post emergence metamifop $200 \mathrm{~g}$ ai ha-1 $^{-1}$; post emergence cyhalofop butyl $100 \mathrm{~g}_{\text {ai ha }}{ }^{-1}$ and two hand weeding on 25 and 45 DAS and unweeded control. The results revealed that the pre-emergence application of pretilachlor + safener at $0.45 \mathrm{~kg}$ ai $\mathrm{ha}^{-1}$ followed by one hand weeding at 45 DAS was effective in controlling all weeds and registered higher yield attributes and yield in drum seeded rice. Further, the post emergence herbicide metamifop $100 \mathrm{~g}$ ai ha ${ }^{-1}$ was found to be superior in controlling grassy weeds as compared to other herbicides and doses. No doubt, the results of two hand weeding are significantly better, but as it is time consuming and laborious, it cannot be recommended at large scale. Hence, pre-emergence application of pretilachlor + safener at $0.45 \mathrm{~kg}_{\text {ai ha }}{ }^{-1}$ followed by one hand weeding at $45 \mathrm{DAS}$ was found to be the best weed management practice in terms of higher weed control efficiency and yield in drum seeded rice cultivation.
\end{abstract}

KEY WORDS : Herbicides, Weed density, Weed dry weight, Yield, Drum seeded rice

How TO CITE THIS ARTICLE : Parthipan, T. (2016). Strategies for weed management in drum seeded rice under puddled condition (Oryza sativa L.). Internat. J. Forestry \& Crop Improv., 7 (1) : 14-18, DOI: 10.15740/HAS/IJFCI/7.1/14-18.

ARTICle Chronical : Received : 15.02.2016; Revised : 04.04.2016; Accepted : 05.05.2016

\section{AUTHOR FOR CORRESPONDENCE}

T. PARTHIPAN, Agricultural College and Research Institute (T.N.A.U.), Eachangkottai, THANJAVUR (T.N.) INDIA 